\title{
Development of Securities Market In Nepal
}

\author{
Santosh Subedi \\ Lecturer \\ Department of Management \\ Janamaitri Multiple Campus, Kuleshwar, Kathmandu, Nepal \\ Email: subedis11@gmail.com
}

\begin{abstract}
The research article is primarily based on development of securities market in Nepal with the aim to analyze the development of securities markets in Nepal. For the accomplishment of the objectives the required data were mainly gathered from secondary sources published by annual report of the Security Board Nepal, different books from library, periodicals, newspaper cuttings, company's magazines etc. From the study, it is found that the number of listed companies has almost been in increasing trend although the growth trend has decreased. This indicates that the NEPSE might have incorporated most of the institutions and thus there is slow growth in listing. Observing the company traded to listed ratios, it can be assumed that NEPSE should monitor the obstacles in the market that are preventing the listed companies to remain untraded.The economic prosperous of the country, the uplift in annual turnover of securities market is quite necessary. Although, the listed companies in NEPSE has been highly dominated by finance companies, the contribution of financial institutions in generating turnover is highest, and the market capitalization of other institutions, which comprises hydropower, promoter share, mutual fund, preference share and other is strongest.
\end{abstract}

Key words: Market Capitalization, Paid up Capital, IPO, NEPSE, Promoter Share, Mutual Fund.

\section{Background of the Study}

A Securities market is an exchange where sale and purchase transactions of securities are conducted on the base of demand and supply. A well-functioning securities market should be able to provide timely and accurate information on the past transactions, liquidity, low transaction costs (internal efficiency) and securities prices that rapidly adjusted to all available information (external efficiency). 
There are two levels of securities markets. Primary Market is the market for new securities issues and is facilitated by underwriting groups. The companies sell their securities to the public directly to the investors through the underwriters (normally investment banks for stock and bond issuance). When the firm is issuing shares for the very first time, it is called Initial Public Offering (IPO). New shares issued by firms whose shares are already trading in the market are called seasoned or secondary issues. Issuing company receives cash from the sale and uses it to expand or fund the operations. After the initial sale, the securities trading will be conducted on the secondary market.

Secondary market, also known as the aftermarket, is the market where the trading of the previous issued securities is conducted. On a secondary market, an investor buys securities from another investor instead of the issuer. It is important that the secondary market provides liquidity and therefore provides continuous information about the market price of the securities (Bhandari, 2013).

Secondary markets are mainly organized in two ways. One is to form a centralized and organized exchange where all buyers and sellers (or their representative agents) meet and conduct trading. The more investors participate in a market, the greater the centralization of that market, and the more liquid the market. The example of this form of secondary market is Nepal Stock Exchange (NEPSE). The other way is Over-The-Counter (OTC) market which a secondary market where securities are traded directly between two parties. Trading occurs via dealers who carry inventories of securities and contact each other by computer, telephone or other electronic network instead of a physical trading floor. Overthe-counter dealers quote a bid price at which they would buy, and an ask price at which they would sell. An example of an over-the-counter securities market is the National Association of Securities Dealers Automated Quotations System.

\section{Research Problems}

Nepalese securities market is very small in comparison with other developed stock markets. There are a few numbers of brokers, limited number of listed companies, very few transactions and most importantly investors are unknown about the pros and cons of the stock market. The market is partially captured by individual investors who buy very little number of shares and therefore they do not bother analyzing the data and information before buying and selling stock. The variety of securities available in the market allows each investor to select asset that suit his risk, preferences and beliefs. But there is lack of different types of securities in the stock market.

Likewise, it is needed to check to how security market affects and is affected by different macro environment factor. So this to answer the following research question:

- What is the present status of securities market in Nepal?

- What are the positions of market capitalization? 


\section{Objectives}

The main objective of this study is to identify the development of the Nepalese security market. The other specific objectives of this study are as follows:

- To assess the development of security market in Nepal.

- To examine the position of market capitalization in Nepal.

\section{Limitations of the Study}

Following are the limitations:

- The present study is based on real aspect of development securities market in Nepal. The study does not consider availability of different instrument and institutions for trading purpose.

- Secondary data has the own limitation (i.e. reporting error) and in case of primary data the respondent sometimes may not be willing to give exact opinion. And some of the questionnaires have been returned by the respondent with incomplete responses.

- This study covers only the 10 years period from $2007 / 08$ to $2016 / 17$.

\section{Literature Review}

Edward, R. D. and et al. (2001), 'Technical Analysis of Stock Trend' focused that a simplified portfolio selection criterion suggested by Sharpe and Mao involves choosing at most $\mathrm{n}$ securities from a universe of $\mathrm{m}$ securities in order to maximize the portfolio's excess-return-to-beta ratio. This study examines alternative solution procedures to achieve this objective, including a gradient procedure whose continuous Knapsack sub problems in $\mathrm{m}$ bounded variables are solved in $0(\mathrm{~m})$ time. The effect on the optimal portfolio of increasing $\mathrm{n}$ is discussed, as well as the relationship between the excess-return-to-beta ratio of an individual security and that of the optimal portfolio. The study concludes with computational experience on problems with $\mathrm{n}$ ranging from 10 to 200 and $\mathrm{m}$ from 500 to 1245 .

Gitaman, L. J. (1998) Principles of Managerial Finance concluded that the perceptions investor relations professionals has held of CSR (Corporate Social Responsibility), the role of IRO (Investor Relation Officer) in communicating CSR and their perceptions of future development. Expectations first and foremost are for greater reporting requirements in general and for communications with investors to become more transparent and more wide-ranging. There will be an expectation that all firms will need to explain their approach to wider stakeholder issues. Investor relations are still a relatively young profession. There is increasing awareness for more effective and impactful communications with mainstream investors. This article develops for understanding of the role of investor relations professionals beyond a traditional form and so adds to our theoretical understanding of the role of investor relations as boundary spanners. In particular, it points to a role of educating the market and impacting on firm strategy. It has implications for the practice 
both of investor relations and of investment management. Investor relations officers need to become more closely involved in the strategic management of their firms.

Gurung, J. B. (2016) 'Growth and Performance of Securities Market in Nepal' The Journal of Nepalese Business Studies assesses that securities market plays a pivotal role in mobilizing savings and channeling them in productive purposes and many more like providing liquidity on securities so that one can minimize the risk and maximize the returns. The study on the securities market performance reveals that there is no synchronization among different securities market performance indicators, but it is true that they almost have depicted an erratic trend during the observed period. This indicates the unstable and poor performance of securities market. Relative to the overall economy, the size of securities market is very small and the liquidity of securities also is poor. These facts suggest that the Nepalese capital market now is passing through a bearish situation. The growth and performance of Nepalese securities market, even after the introduction of new mechanism in 1993/94, are not satisfactory though it is improving gradually.

'The Performance of Nepalese IPOs' by Dahal (2007) assesses the performance of Nepalese IPOs and relates them to potential factors. The study finds that the Nepalese IPOs are heavily oversubscribed and provide the investors with the market adjusted excess rate of return leading to the conclusion that Nepalese IPOs are underpriced too. The study finds that the NEPSE Index and the subscription as times of issue have significant predicting strength on the performance of IPOs. The study results show that phenomenon of oversubscription can be explained by the firm size and the debt equity ratios.

'Nepalese Securities Market: Regulation and Development' by Thapa (2007) conclude that the study reveals the weak performance of the market and slow pace of development. Several efforts were made to reform the market and improve market performance. However, these efforts have not become fruitful because of structural deficiencies in market mechanism. Lack of appropriate and standard legal framework has been the major reason for not improving efficiency of regulation. Various kinds of frauds and malpractices from the service providers have been noted. Investors are being the victims of market hypes, as their awareness level could not be raised adequately. SEBON as being the regulator of securities market must be responsible for proper functioning of market. With the enactment of new Securities Act, SEBON should gear up for the overall development of the market. For this SEBON should give maximum emphasis to bring into implementation of the various regulations as provisioned by the Act. A prerequisite for this would be the capacity building of the regulator with adequate authority and operational autonomy, proper resources and experts, and technological enhancement. SEBON should focus to play its role in infrastructure development, improvement of professionalism of the market participants, enhance disclosure standards, supervise market and take enforcement actions to ensure fairness and transparency in the market. 
'Efficient market hypothesis and behavior of share prices: the Nepalese evidence' (2010) by Pradhan and KC's purpose of this study is to assess equity share price behavior in Nepal and testing the hypothesis that share price changes are independent. The study is based on three years' time series of weekly indices as well as time series of weekly stock prices of 26 individual companies for the same period. The study revealed that the time series of changes in stock indices are independent to each other. The majority of the auto-correlations are zero, leading to the conclusion that the series is truly random to a large extent. Concerning individual companies, the time series of changes in stock prices of the frequently traded stock and less frequently traded stocks show a clear distinction in their behavior. Auto-correlation test results indicated that the random walk hypothesis is true for less frequently traded stocks and the same is not consistent with the prices of highly traded stocks. There is a greater dependence in the series of past prices and the present price will have significant influences on the changes in the future prices of such companies.

'Bond market in Nepal' by Vaidya (2010) aims to deal with the status, shortcomings, and measures of bond market development in Nepal based on review and observation. After the establishment of Securities Board of Nepal in 1993, the capital market of Nepal experienced a gradual growth. In this period, the equity market outpaced the growth in the bond market. The importance of bond market in Nepal is pivotal considering current need to invest in infrastructure development project like hydropower, transportation, real estate, etc. The bond market in Nepal is yet to be fully embraced by institutions and investors as a platform to match their respective investment needs. Similarly, the regulatory authorities regulating this market are yet to be proactive for its development. This study concludes that development of bond market is imperative for the further development of capital market of Nepal. The bond market not only serves particular borrowing needs efficiently but also helps in effective functioning of the financial market. A developed bond market will help avoid concentration in bank as only source of financial intermediation. The bond market in Nepal is yet to develop due to various problems. A focused effort has to bve made from concerned stakeholders to address problems faced by the market. Some of the measures include develop the government bond market, improve regulatory environment, strengthen regulatory supervision, rationalize tax treatment and providing tax incentive, broaden the institutional investor base, and facilitate in developing specialized market intermediaries.

\section{Research Methodology}

Research methodology refers to the various methods of practices applied by the researcher in the entire aspect of the study. It is the plan, structure and strategy of investigations conceived to answer the research question or test the research hypothesis. It includes different statistical tools such as standard deviation, t-test, correlation analysis, regression analysis, ANOVA and coefficients. 


\section{Research Design}

A research design is a plan, structure, and strategy to obtain the objectives of the study. Hence, the descriptive as well as analytical research design has been used. Descriptive research design has clearly described the characteristics and phenomenon of securities market development and issues.

\section{Sources of Data}

The secondary data have been collected from the various sources like annual reports of SEBON, NEPSE and Economic Survey published by Ministry of Finance. The main source of data is annual report of the SEBON. Besides annual report, various bulletins available and useful to the study are also taken into consideration. The research is mainly based on the secondary data. The study covered the period of 10 years from the fiscal year 2007/08 to 2016/17. Data are taken from NEPSE and SEBON and all the analysis is made on the basis of these ten years' data. Also, the questionnaires are disbursed and the primary data analysis is done.

\section{Data Collection Procedure}

The secondary source of data are collected from the annual report of the Security Board Nepal, different books from library, periodicals, newspaper cuttings, company's magazines etc. Guidelines and unpublished thesis, research work that directly related to the financial performance and stock market would form secondary data for the purpose of this study.

\section{Presentation and Analysis of Secondary Data}

This part has reveals the presentation and analysis of secondary data. Secondary data also helps to supports the development of securities market. The main purpose of the study is the development of the securities market in Nepal.

Table 1: No. of Listed Company in NEPSE

\begin{tabular}{|c|c|}
\hline Fiscal Year & Listed Companies \\
\hline $2007 / 08$ & 135 \\
\hline $2008 / 09$ & 142 \\
\hline $2009 / 10$ & 159 \\
\hline $2010 / 11$ & 176 \\
\hline $2011 / 12$ & 207 \\
\hline $2012 / 13$ & 216 \\
\hline $2013 / 14$ & 230 \\
\hline $2014 / 15$ & 232 \\
\hline $2015 / 16$ & 232 \\
\hline $2016 / 17$ & 229 \\
\hline
\end{tabular}


Table 1 it can be concluded that the total number of listed company in the fiscal year 2007/08 was only 135 but at the end of study period 2016/17 the total number of company was 229 , which is the highest number ever listed in the last 10 years.

\section{Market Turnover Volume and Value}

Annual turnover constitutes an important indicator for measuring the nation's economic activity. It also reflects the stock market liquidity as higher the amount of trading of stock market size higher is the stock market liquidity

Table 2: Annual Turnovers in Value and Volume

\begin{tabular}{|c|c|c|}
\hline Year & Annual in value(million) & Annual in volume (000) \\
\hline $2007 / 08$ & 8360 & 18147.3 \\
\hline $2008 / 09$ & 22821 & 28599.8 \\
\hline $2009 / 10$ & 21681 & 30547.2 \\
\hline $2010 / 11$ & 11581 & 26261.4 \\
\hline $2011 / 12$ & 6665 & 26240.4 \\
\hline $2012 / 13$ & 10272.8 & 41478.9 \\
\hline $2013 / 14$ & 22048.9 & 81571.7 \\
\hline $2014 / 15$ & 77298.6 & 214143.56 \\
\hline $2015 / 16$ & 65331.6 & 159717 \\
\hline $2016 / 17$ & 163950 & 302000 \\
\hline
\end{tabular}

Source: SEBON Annual Report, (2016/17)

From table 2, it can be concluded that the highest annual turnover in value was in 20015/16 and lowest in 2007/08, whereas, the volume of market turnover was highest in the year 2016/17 and lowest in the year 2007/08. The performance of the market during the period of $2007 / 08$ to $2016 / 17$, as shown by the various indicators: instability of the government, strike, investors' interest to other sectors like real estate and others have greatly influenced the securities market of Nepal in the recent year and thus the NEPSE index has been fluctuated. Despite this, it can be concluded that the affectionate of the securities market in investors have been growing in greater extent and thus investors are defraying more market price for taking the possession on shares. The increasing trend of market capitalization indicates increase in market price per share of the companies listed, which indicates positive impact of securities market on the investors.

\section{Number of transaction and listed securities in NEPSE}

Securities that are listed in the stock exchange have its own code of conduct. The present system in the stock exchange is that the securities have to be listed in the stock exchange within the 45 days after the allotment. And listing and delisting of securities are based on the rules and regulations of the stock exchange. 
Table 3: No. of Listed and Transacted of Securities in NEPSE

\begin{tabular}{|c|c|c|c|c|}
\hline Year & No. of Transaction & \% Change & $\begin{array}{c}\text { Listed } \\
\text { Securities(000) }\end{array}$ & Percent change \\
\hline $2006 / 07$ & 97374 & - & 226540 & - \\
\hline $2007 / 08$ & 120510 & 23.76 & 243504 & 7.49 \\
\hline $2008 / 09$ & 150800 & 25.13 & 321131 & 31.88 \\
\hline $2009 / 10$ & 209091 & 38.66 & 637868 & 98.63 \\
\hline $2010 / 11$ & 213733 & 2.22 & 821746 & 28.83 \\
\hline $2011 / 12$ & 302364 & 41.47 & 1033674 & 25.79 \\
\hline $2012 / 13$ & 293489 & -2.94 & 1140081 & 10.29 \\
\hline $2013 / 14$ & 292366 & -0.38 & 1297841 & 13.84 \\
\hline $2014 / 15$ & 566389 & 93.73 & 1614978 & 24.43 \\
\hline $2015 / 16$ & 477278 & -15.73 & 2553109 & 58.1 \\
\hline $2016 / 17$ & 831997 & 74.32 & 3642900 & 42.68 \\
\hline
\end{tabular}

Source: SEBON Annual Report, (2016/17)

The above table 3 shows that the number of transactions is fluctuating indifferent fiscal year. In the fiscal year 2007/08 there was a growth rate by 23.76 percent. fiscal year $2012 / 13$ and $2013 / 14$, there was a negative change in transactions by -2.94 and -0.38 respectively, and again in the fiscal year 2015/16 there was negative change in the transaction by -15.73 . This shows that market is not in stable position or else there would have been a steady changing. There could be unfavorable economic policy of government affecting the growth.

The significant change can be traced in the fiscal year $2014 / 15$ by 93.73 percent as compared to the growth rate of 3.56 percent of fiscal year 2013/14. This is due to a huge number of passive investors who cannot take risk in highly volatile market.

Securities that are listed in the stock exchange have its own code of conduct. The present system in the stock exchange is that the securities have to be listed in the stock exchange within the 45 days after the allotment. And listing and delisting of securities are based on the rules and regulations of the stock exchange. As such the numbers of listed securities was highest in the fiscal year 2016/17 with 3642900 numbers and lowest in the year $2007 / 08$ with 243504 . The highest percent change was in the year $2009 / 10$ by 98.63 percent and lowest was in the year $2007 / 08$ by 7.49 percent. There is positive growth rate in the number of listed securities.

\section{Market Capitalization}

One of the important ways of measuring securities market size is the Market Capitalization. Market capitalization is the total market value of all company's outstanding shares. Note 
that market capitalization is a market estimate of a company's value, based on perceived future prospects, economic and monetary conditions. Market capitalization simply refers to the market price of listed securities. It is derived by multiplying the number of listed securities of all companies by the closing market price of corresponding securities and summing up them.

The following figure shows the market capitalization and of Nepalese securities market.

Table 4: Market Capitalization

\begin{tabular}{|c|c|c|}
\hline Year & $\begin{array}{c}\text { Market Capitalization } \\
\text { (Rs in millions) }\end{array}$ & $\begin{array}{c}\text { Percent change in Market } \\
\text { Capitalization }\end{array}$ \\
\hline $2006 / 07$ & 96813.7 & - \\
\hline $2007 / 08$ & 186301.3 & 92.43 \\
\hline $2008 / 09$ & 366247.5 & 98.03 \\
\hline $2009 / 10$ & 512939.1 & 40.05 \\
\hline $2010 / 11$ & 376871.4 & -26.53 \\
\hline $2011 / 12$ & 323484.3 & -14.17 \\
\hline $2012 / 13$ & 371115.7 & 14.72 \\
\hline $2013 / 14$ & 514492.1 & 38.63 \\
\hline $2014 / 15$ & 1057166 & 105.48 \\
\hline $2015 / 16$ & 989404 & -6.41 \\
\hline $2016 / 17$ & 1890130 & 91.04 \\
\hline
\end{tabular}

Source: SEBON Annual Report, (2016/17)

The base year is taken 2006/07.

The computation is as follows:

Percent Change in $\mathrm{M} \mathrm{C}=\frac{\text { This year MC- Base year MC }}{\text { Base year Market Capitalization }} \times 100$

Table 4 shows that the market capitalization of the listed companies has followed increasing trend in 2014/15, decreasing in 2015/16 and after increase in 2016/17. The market capitalization has ranged from Rs186301.3 million in the fiscal year 2007/08 to Rs. 1890130millions in the fiscal year 2016/17. The Percentage change rate in market capitalization is highest (105.48\%) in the fiscal year 2014/15 and lowest $(-26.53 \%)$ in the fiscal year 2010/11. The increasing trend of market capitalization indicates increase in market price per share of the companies listed, which indicates positive impact of securities market on the Investors. The highly fluctuation in market capitalization is unfavorable monetary policy of government as well as huge number of passive investors. 


\section{Analysis of Percent of Turnover on Market Capitalization}

Table 5: Analysis of Percent of Turnover on Market Capitalization

(in Millions)

\begin{tabular}{|c|c|c|c|}
\hline Fiscal Year & $\begin{array}{c}\text { Market } \\
\text { Capitalization }\end{array}$ & Annual Turnover & $\begin{array}{c}\text { \% of Turnover on } \\
\text { Market Capitalization }\end{array}$ \\
\hline $2007 / 08$ & 186301.3 & 8360 & 3.56 \\
\hline $2008 / 09$ & 366247.5 & 22821 & 4.48 \\
\hline $2009 / 10$ & 512939.1 & 21681 & 6.23 \\
\hline $2010 / 11$ & 376871.4 & 11581 & 4.22 \\
\hline $2011 / 12$ & 323484.3 & 6665 & 3.14 \\
\hline $2012 / 13$ & 371115.7 & 10272.8 & 2.06 \\
\hline $2013 / 14$ & 514492.1 & 22048.9 & 2.77 \\
\hline $2014 / 15$ & 1057166 & 77298.6 & 4.29 \\
\hline $2015 / 16$ & 989404 & 65331.6 & 7.31 \\
\hline $2016 / 17$ & 1890130 & 163950 & 6.60 \\
\hline
\end{tabular}

Source: SEBON Annual Report (2016/17)

Table 5 shows market capitalization in year 2007/08 is 186301.3 and it grows continuously up to 512939.07 in $2009 / 10$ than it decreases to 376871.37 and 323484.34 in 2010/11 and 2011/12 continuously, then it increases to 371115.74 and 514492.1in 2013/14 and 2014/15, then after decrease trend in 2015/16 and increase in 2016/17. In above figure the highest Market Capitalization is in 2016/17.

The Annual Turnover in 2007/08 it increases up to 2008/09 and reached 22820.8 then it continuously decreases in 2009/10,2010/11 and 2011/12 and reached to 6665.33 then it increase in 2012/13 and 2013/14. Last two year turnover reached to 989404 and 1890130 in 2015/16 and 2016/17 respectively. Nepal stock market is the still at an underdeveloped stage, characterized by legal inadequacy, low resource availability to the regulator, low liquidity, double taxation on dividend and capital gain tax, poor corporate governance practice, low involvement of institutional investors, poor discloser practices, high cost of public issue, high transaction cost, lack of enforcement of accounting and auditing standard, lack of qualified manpower, lack of sufficient knowledge to the investor etc. Very limited numbers of shares are available for trading out of total shares listed in NEPSE.

\section{Paid up Capital}

Total paid up capital is the function of the number of listed securities of traded companies and paid up value per share. Market capitalization simply refers to the market price of listed securities. It is derived by multiplying the number of listed securities of all companies by the closing market price of corresponding securities and summing up them. Thus, the paid up capital indicates the actual investment in the financial assets whereas market capitalization indicates the present value of the investments. 
Table 6: Percentage Change in Paid- up Value

\begin{tabular}{|c|c|c|}
\hline Year & Paid up value (Rs in millions) & \% change in Paid up value \\
\hline $2007 / 08$ & 29465 & 8.95 \\
\hline $2008 / 09$ & 61140.4 & 35.17 \\
\hline $2009 / 10$ & 79356 & 29.81 \\
\hline $2010 / 11$ & 100238 & 30 \\
\hline $2011 / 12$ & 110611 & 26 \\
\hline $2012 / 13$ & 126064 & 10 \\
\hline $2013 / 14$ & 126064 & 14 \\
\hline $2014 / 15$ & 145090 & 15.09 \\
\hline $2015 / 16$ & 210590 & 45.14 \\
\hline $2016 / 17$ & 321820 & 52.82 \\
\hline
\end{tabular}

Sources: SEBON: Annual Reports; (2016/17)

The amount of paid up capital has increased in every subsequent FYs. However, the annual growth rate has not increased in the same ratio. Paid up capital of overall listed securities has increased from Rs.29465 million in 2007/08 to Rs.321820 million at the end of 2016/17. This indicates the pace of investment in corporate sector through securities is still in snail's pace. At the end of the fiscal year 2016/17, the paid up value of listed securities increased by $52.82 \%$ amounting to Rs. 321820 million as compared to the last fiscal year which amount to Rs.210590. The highest increase of paid up value was in the year $2016 / 17$ by $52.82 \%$ and lowest in the year $2007 / 08$ by $8.95 \%$.

The paid up value of listed securities has been increasing steadily though not in the same rate every year. This is because the people have become more aware of the stock market. They have started realizing about the capital gain and how profitable it can be while investing in the market.

\section{Correlation Analysis}

Correlation is the relationship between two or more variables (only one variable dependent and one or more variable independent). Correlation analysis is defined as the statistical technique which measures the degree of relationship between the variables. Correlation analysis does not tell anything about cause and effect relationship. There are three types of correlation: simple, partial and multiple. But our concern is only the simple correlation. A method of measuring correlation is called Pearson's coefficient of correlation. 
Table 7: Correlation Analysis

\begin{tabular}{|c|c|}
\hline & TV \\
\hline MC Pearson Correlation & $.950^{* *}$ \\
Sig. (2-tailed) & .000 \\
$\mathrm{~N}$ & 10 \\
\hline
\end{tabular}

**. Correlation is significant at the 0.01 level (2-tailed).

Showing the above table 7, the Pearson Correlation coefficient between market capitalization and turnover value among Nepalese securities market is 0.950 , which implies that the two variables are positively correlated. The positive coefficient of correlation is 0.950 at $1 \%$ significant level.

\section{Hypothesis}

- H01: There no significant relationship between market capitalization and Turnover value

- The correlation analysis shows that there is a positive correlation between market capitalization and Turnover value. The correlation is significant at $1 \%$ where p-value is less than alpha i.e. $0.00<0.01$.

- Hence, the null hypothesis (H01) is rejected. It means alternative hypothesis accepted.

\section{Regression Analysis}

The meaning of the word regression is stepping or returning back to the average value. The term was first developed by Sir Francis Galton in 1877.These days there is growing tendency of the modern writers to use the term estimating line instead of regression line because the expression estimating line is more clarification in character. We can explain the few definitions of the term regression:

Regression is the measure of the average relationship between two or more variables in terms of the original units of the data.

The term regression analysis refers to the methods by which estimates are made of the values of variables from knowledge of the values of one or more other variables and to the measurement of the errors involved in the estimation process.

Regression analysis is used as a tool of determining the strength of relationship between two variables. Thus, it is a statistical device, with the help of which we can predict the value of one variable when the value of other variable is known the unknown variable, which we have to predict, is called dependent variable and the variable which value is known is called independent variable the line of regression is 
$\mathrm{Y}=\alpha_{0}+\beta \mathrm{iXi}++\varepsilon \mathrm{i}$

Where;

$\mathrm{Y}=$ Market capitalization (Dependent variable)

$\alpha_{0}=$ Constant term of the model

$\beta \mathrm{i}=$ Coefficient of slope of regression model

$\varepsilon i=$ Error Term

$\mathrm{Xi}$; = Turnover value (independent variable)

Table below show the findings of regression analysis between market capitalization and turnover value.

Table 8: Regression Analysis - Model Summary

\begin{tabular}{|c|c|c|c|c|}
\hline Model & R & R Square & Adjusted R Square & Std. Error of the Estimate \\
\hline 1 & $.950(a)$ & .903 & .891 & .09805 \\
\hline
\end{tabular}

a. Predictors: (Constant), $T V$

Model summary indicate that the $\mathrm{R}$ square also knows as coefficient of determination which can helps the analyzing variance. The $r$ square value is 0.903 which means $90.3 \%$ variation in market capitalization between turnover values. However, the remaining $9.7 \%$ is still unexplained in this research.

Adjusted R square is 0.891 which means $89.1 \%$ variation market capitalization between turnover value. This shows that moderate relationship between independent variable and dependent variable market capitalization among turnover value in securities market in Nepal.

Table 9: ANOVA

\begin{tabular}{|c|c|c|c|c|c|c|}
\hline \multicolumn{2}{|r|}{ Model } & Sum of Squares & df & Mean Square & $\mathbf{F}$ & Sig. \\
\hline 1 & Regression & .715 & 1 & .715 & 74.430 & $.000 \mathrm{a}$ \\
\hline & Residual & .077 & 8 & .010 & & \\
\hline & Total & .792 & 9 & & & \\
\hline
\end{tabular}

a. Predictors: (Constant), TV

b. Dependent Variable: $M C$

Based on ANOVA, the p-value is 0.00 which is less than alpha value 0.01 . Therefore, the model is a good predictor of the relationship between the dependent and independent variables. As a result, the independent variables turnover value (TV) and market capitalization (MC) are significant in explaining the variance turnover value between market capitalizations. 
Table 10: Coefficients

\begin{tabular}{|c|c|c|c|c|c|c|}
\hline \multirow{2}{*}{\multicolumn{2}{|c|}{ Model }} & \multicolumn{2}{|c|}{$\begin{array}{c}\text { Unstandardized } \\
\text { Coefficients }\end{array}$} & \multirow{2}{*}{$\begin{array}{c}\begin{array}{c}\text { Standardized } \\
\text { Coefficients }\end{array} \\
\text { Beta }\end{array}$} & \multirow[t]{2}{*}{$\mathbf{t}$} & \multirow[t]{2}{*}{ Sig. } \\
\hline & & B & Std. Error & & & \\
\hline & (Constant) & 3.036 & .313 & & 9.709 & .000 \\
\hline & TV & .613 & .071 & .950 & 8.627 & .000 \\
\hline
\end{tabular}

a. Dependent Variable: $M C$

Taking two dimensions of Market capitalization (MC) is constant and turnover value (TV) is independent variable (X1). The model is constructed with equation as below:

$$
\hat{\mathrm{Y}}=\alpha+\beta_{1} \mathrm{X}_{1}+\text { ei. }
$$

Based on the coefficients, the regression equation for the Market capitalization can be written as:

$$
\hat{Y}=3.036+0.613 X_{1}
$$

The table 4.12 also shows that all independent variables such as turnover value is significant results since their respective p-values are less than level of significant $(\mathrm{p}<0.00)$.This illustrates that 1 unit increase turnover value and market capitalization increase respectively. The beta of turnover value is 0.950 which is the most dominant the market capitalization in securities market. The correlation coefficient shows that there is significance between market capitalization and turnover value.

\section{Conclusions}

Most of the capital market indicators like market capitalization and NEPSE Index seem to be increased up to FY 2008/09\&2009/10, and then decreased during the fiscal year $2010 / 11$ to $2012 / 13$ and after increase in $2013 / 14$ to $2016 / 17$. The number of listed companies has almost been in increasing trend although the growth trend has decreased. This indicates that the NEPSE might have incorporated most of the institutions and thus there is slow growth in listing. Observing the company traded to listed ratios, it can be assumed that NEPSE should monitor the obstacles in the market that are preventing the listed companies to remain untraded.

The economic prosperous of the country, the uplift in annual turnover of securities market is quite necessary. Although, the listed companies in NEPSE has been highly dominated by finance companies, the contribution of financial institutions in generating turnover is highest, and the market capitalization of other institutions, which comprises hydropower, promoter share, mutual fund, preference share and other is strongest. A finding of the study is somehow similar with previous research papers. 


\section{References}

Bhandari, D. B. (2013). Financial Institutions and Markets, Kathmandu: Asmita Books Publication.

Burger, J. D. and et al. (2015). 'Bond Market Development in Developing Asia', ADB Working Paper Series, 448.

Demirgue, A. \& Levire, R. (1995). 'Stock Market Development and Financial Intermediaries', The World Bank Policy Research, 10, 1462.

Edward, R. D. and et al. (2001). Technical Analysis of Stock Trend (8th ed.), London: CRC press.

Gitaman, L. J. (1998). Principles of Managerial Finance, New York: Harper \& Row Publishers, Inc.

Gurung, J. B. (2016). 'Growth and Performance of Securities Market in Nepal', The Journal of Nepalese Business Studies, Vol. I No. 1 Dec. 2016.

Koirala, P. and Bajracharya, P. (2017). 'Nepalese Capital Market: Issues and Challenges', Economic Review, Vol. III, No. 2, Dec. 2016.

Mainali, P. K. (2014). 'Problems and Prospects of Stock Market in Nepal', SEBON Journal, 5: 35-58.

Manandhar, K. D. et al. (2011). Managerial Finance, Kathmandu: Khanal Publication.

Ministry of Finance (2017). Economic Survey, Kathmandu, Government of Nepal.

Mishra, R. K. (2018). 'Capital Market Efficiency and Economic Growth: The Case of India', European Journal of Economics, Finance and Administrative Sciences 27(27):130-138 ·

Securities Board, Nepal. (2016). Annual Report, Jawalakhel, Lalittpur 